\title{
Profil Resistensi Antimikroba dari Flora Normal dalam Kavum Nasi Petugas Kamar Operasi Bedah Jantung dan Petugas Pasca Operasi Intensive Coronary Care Unit RSUP H. Adam Malik Medan
}

\author{
${ }^{1}$ Fani A. Irma \\ ${ }^{2}$ Ricke Loesnihari \\ ${ }^{3}$ Nizam Akbar
}

\author{
${ }^{1}$ Departemen/SMF Patologi Klinik Fakultas Kedokteran Universitas Sumatera Utara/ \\ RSUP Haji Adam Malik Medan \\ ${ }^{2}$ Departemen Kardiologi Fakultas Kedokteran Universitas Sumatera Utara \\ ${ }^{3}$ Bagian Patologi Klinik Fakultas Kedokteran Universitas Muhammadiyah Sumatera Utara \\ Email: faniirma68@gmail.com
}

\begin{abstract}
Nosocomial infection often occurs in hospitalized patients due to microbial contamination. This study was aimed to obtain the profile of microbes in nasal cavities of hospital personnel by identification the microbial pattern, therefore, the microbial resistance to several antimicrobial groups could be determined. This was an observational analytical study with a cross sectional design. Subjects were hospital personnel at the Cardiac Surgery room and at the Intensive Coronary Care Unit (ICCU) room of H. Adam Malik General Hospital, Medan. Specimens of nasal cavity swabs were taken from all subjects, and then were cultured and tested for antimicrobial sensitivity. From 37 subjects, the most common bacteria found were S. epidermidis (40\%), S. saprophyticus (21\%), and S. aureus (12\%). The antimicrobial susceptibility test showed that sufamethoxsazole had the highest resistance while erythomycin still had good sensitivity. At the ICCU room, amikacin showed better sensitivity than doxycyclin. Amoxiclav had the highest sensitivity, meanwhile from the floroquinolone class, norfloxacin had better sensitivity than ciprofloxacin. The microbes were still sensitive to cephalosporin class but were resistant to vancomycin. Conclusion: S. epidermidis, S. saprothyticus, and S. aureus were the most commonly found microbes in the nasal cavities of hospital personnel. The nasal cavity microbes were still sensitive to erythromycin, amikacin, amoxiclav, norfloxacin, and cephalosporin group.
\end{abstract}

Keywords: nosocomial infection, nasal cavity, antimicrobial resistance, antimicrobial sensitivity

\begin{abstract}
Abstrak: Infeksi nosokomial sering terjadi pada saat pasien dirawat di rumah sakit akibat adanya kontaminasi mikroba yang berada di rumah sakit. Penelitian ini bertujuan untuk mendapatkan pola mikroba kavum nasi dari petugas rumah sakit melalui identifikasi mikroba sehingga dapat ditentukan pola resistensi mikroba terhadap berbagai macam golongan antimikroba. Jenis penelitian ialah analitik observasional dengan desain potong lintang. Subyek penelitian ialah petugas di kamar operasi bedah jantung dan ruang pasca operasi ICCU di RSUP H. Adam Malik Medan. Pengambilan spesimen swab kavum nasi dilakukan pada semua subyek, dilanjutkan dengan pembiakan serta uji resistensi antimikroba. Dari 37 subyek didapatkan bakteri terbanyak yaitu S. epidermidis (40\%), diikuti oleh S. saprothyticus (21\%), dan S. aureus (12\%). Uji sensitivitas terhadap antimikroba lini pertama mendapatkan sulfametoksasol merupakan antimikroba yang paling tinggi resistensinya sedangkan eritromisin merupakan antimikroba yang masih baik sensitivitasnya. Untuk ruang ICCU, sensitivitas terhadap amikasin masih lebih baik dibandingkan doksisiklin. Amoksiklav merupakan antimikroba yang sensitivitasnya sangat baik, sedangkan dari golongan florokuinolon, norfloksasin memiliki sensitivitas yang lebih baik dibanding siprofloksasin. Golongan sefalosporin masih memiliki sensitifitas yang baik, sedangkan vankomisin sudah resisten. Simpulan: Bakteri terbanyak didapatkan dalam kavum nasi ialah $S$. epidermidis, S. saprothyticus, dan S. aureus. Antimikroba yang masih sensitif yaitu eritromisin, amikasin, amoksiklav, norfloksasin, dan golongan sefalosporin.
\end{abstract}

Kata kunci: infeksi nosokomial, kavum nasi, resistensi antimikroba, sensitivitas antimikroba 
Infeksi nosokomial merupakan infeksi yang didapatkan pasien selama dirawat di rumah sakit. Hal ini perlu mendapat perhatian karena akan memengaruhi keberhasilan penanganan dan peningkatan stres emosional pasien yang pada akhirnya akan memperpanjang masa perawatan di rumah sakit bahkan dapat menyebabkan kondisi yang fatal. $^{1-3}$

French National Prevalence Survey melaporkan gambaran infeksi nosokomial yang paling sering terjadi di rumah sakit sebagai berikut: infeksi saluran kemih (UTI) 35\%, infeksi luka operasi/infeksi daerah operasi (SSI) 20\%, pneumonia nosokomial (VAP) 15\%, bakteremia nosokomial (BSI) $15 \%$, dan infeksi nosokomial lainnya. Jenis mikroorganisme (infeksi endogen maupun infeksi eksogen), daya tahan pasien, faktor lingkungan serta resistensi terhadap antimikroba, merupakan faktor-faktor yang dapat memengaruhi perkembangan infeksi nosokomial di rumah sakit. ${ }^{1,4}$ The Centre for Disease Control and Prevention (CDC) menyatakan bahwa $30 \%$ dari infeksi nosokomial dapat dicegah dengan membuat sistem pedoman kontrol infeksi di rumah sakit, sehingga perpindahan bakteri melalui berbagai port de entre antara tenaga medis dan pasien dapat dicegah. ${ }^{1,5-7}$

Pemeriksaan spesimen $s w a b$ di daerah kavum nasi atau tangan petugas dapat dilakukan untuk memberikan data adanya infeksi nosokomial dari petugas ke pasien. ${ }^{1}$ Di dalam kavum nasi dapat ditemukan berbagai macam mikroorganise antara lain S. epidermidis, S. aureus, S.pneumoniae, Haemophilus spp, dan $S$. pyogenes yang dapat mengalami kolonisasi di dalam kavum nasi. Mikroorganisme ini kemudian mengalami transmisi dari petugas ke pasien-pasien yang sedang dirawat. ${ }^{1,8-13}$

Penelitian oleh Tammelin et $\mathrm{al}^{14} \mathrm{di}$ University Hospital Uppsala, Sweden, terhadap petugas di Departemen Bedah Toraks dan Jantung Vaskular pada tahun 2001-2002 melaporkan bahwa di kamar operasi didapatkan nasal carriage dari $S$. aureus sebesar $15,6 \%$ sedangkan di ICU didapatkan nasal carriage sebesar 19,3\%, dan di bangsal sebesar $25,8 \%$.
Resistensi antimikroba berhubungan dengan tingkat keparahan penyakit, serta meningkatkan masa rawat inap dan biaya pengobatan. Resistensi terhadap antimikroba di negara berkembang dapat disebabkan oleh adanya perilaku sosial ekonomi dan penyalahgunaan antimikroba oleh kalangan praktisi kesehatan, praktisi yang tidak terampil, masyarakat awam, kualitas obat yang buruk, kondisi unhygiene untuk penyebaran bakteri resisten, serta pengawasan yang tidak memadai. ${ }^{15-17}$

Farzana et al $^{15}$ melakukan nasal swab pada petugas berbagai bangsal serta petugas kesehatan lainnya di Children Hospital Complex, Multan, mendapatkan $112(86,8 \%)$ sampel positif paling sedikit satu Staphylococcus spesies, 9 spesimen $(6,9 \%)$ terdiri dari dua spesies Staphylococcus yang berbeda, satu spesimen terdiri dari K. pneumoniae dengan Staphylococci, 62 spesimen $S$. aureus, dan $45,7 \%$ coagulase negative Staphylococci. Terhadap $S$. aureus, vankomisin merupakan antibiotik yang paling sensitif, diikuti oleh sefalotin (92\%), siproflokasin (90\%), doksisiklin (81\%), amikasin $(74 \%)$, oksasilin $(70 \%)$, asam fusidik (70\%), eritromisin (55\%), ampisilin $11 \%$, dan penisilin $3 \% .^{15,18-20}$

Penelitian ini bertujuan untuk mendapatkan profil resistensi antimikroba dari bakteri kavum nasi pada petugas di kamar operasi Bedah Jantung dan ruang pasca operasi Intensive Coronary Care Unit (ICCU) di RSUP Haji Adam Malik Medan.

\section{METODE PENELITIAN}

Penelitian ini dilaksanakan pada bulan Pebruari 2011 di Departemen Patologi Klinik dan Departemen Ilmu Kardiovaskular, Instalasi Bedah Pusat RSUP H. Adam Malik Medan. Jenis penelitian ialah analitik observasional dengan desain potong lintang. Pengambilan sampel penelitian menggunakan total sampling pada seluruh petugas tetap yang telah bekerja lebih dari satu tahun, baik dokter, perawat, petugas kebersihan, maupun petugas lainnya yang bekerja di kamar operasi Bedah Jantung dan pasca operasi ICCU yang tidak sedang mengonsumsi antimikroba. 
Pelaksanaan penelitian diawali dengan pemberian informed consent kepada semua subyek penelitian, kemudian dilakukan pengambilan spesimen dengan menggunakan kultur swab di daerah anterior nares. Spesimen yang diambil dibawa ke laboratorium untuk terlebih dahulu dilakukan pewarnaan Gram untuk melihat representasi bakteri dalam spesimen. Selanjutnya dilakukan kultur pada tiga media yang berbeda, yaitu media agar darah, media agar MacConkey, dan media agar chocolate. Media agar darah digunakan untuk melihat terjadinya hemolisis pada beberapa mikroorganisme yang diakibatkan oleh produk enzim ekstrasel (streptolisin $\mathrm{O}$ ) yang bereaksi dengan eritrosit dan bersifat antigenik. $^{21,22}$ Pengambilan swab kultur, dilanjutkan dengan penanaman kuman menggunakan goresan secara zig-zag, kemudian ditutup dan dimasukkan ke dalam inkubator pada suhu $37^{\circ} \mathrm{C}$, dibiarkan selama 24 jam. Bila koloni yang tumbuh ialah Gram positif, akan dilanjutkan dengan pemeriksaan identifikasi untuk uji katalase. ${ }^{23}$ Bila terbentuk gas, berarti bakteri tersebut ialah Staphylococcus, dan dilanjutkan dengan API Staph. ${ }^{24}$ Bila tidak terbentuk gas, untuk Streptococcus $\beta$ hemolyticus pada agar darah, tampak adanya zona hemolisis yang luas dan terang. Kemudian dilakukan uji bacitracin; bila sensitif, bakteri tersebut ialah $S$. pyogenes tetapi bila resisten, bakteri tersebut ialah $S$. agalactiae. Untuk Streptococcus $\alpha$ hemolyticus, akan terbentuk zona hemolisis parsial yang berwarna kehijauan, selanjutnya dilakukan uji optocin; bila sensitif, kuman tersebut ialah $S$. pneumonia tetapi bila resisten, kuman tersebut ialah $S$. viridans. Untuk Streptococcus $\gamma$ hemolyticus, tidak terjadi hemolisis sehingga tidak terlihat perubahan pada permukaan koloni.

Untuk menumbuhkan kuman Gram negatif maka spesimen ditanam dalam media agar MacConkey. ${ }^{21,22}$ Jika terjadi pertumbuhan maka dilanjutkan untuk identifikasi bakteri dengan API $20 \mathrm{E}$.

Media agar ketiga yang digunakan ialah media agar chocolate yang merupakan media non selektif, varian dari agar blood. Agar chocolate digunakan untuk pertumbuhan bakteri saluran pernafasan yang fastidious, seperti $H$. influenzae. ${ }^{21,25}$

Bila terdapat pertumbuhan pada media-media di atas maka dilakukan pengecatan Gram kembali untuk identifikasi bakteri.

Agar Muller Hinton digunakan untuk uji kepekaan bakteri terhadap obat-obatan yang bertujuan untuk mengetahui obat antimikroba yang dapat digunakan untuk mengatasi infeksi oleh mikroba tersebut. ${ }^{22}$ Uji kepekaan terhadap obat antimikroba digunakan melalui cara metode difusi cakram, yaitu dengan cara Kirby-Bauer. Tiga sampai lima koloni kuman yang tumbuh pada media biakan diambil dengan ose dan dimasukkan kedalam cairan $\mathrm{NaCl}$ $0,9 \%$ ( $\pm 5 \mathrm{ml})$, kemudian suspensi dibandingkan dengan standar kekeruhan $\mathrm{Mc}$ Farlan 0,5. Cakram antibiotik yang digunakan sesuai dengan bakteri yang sering dijumpai pada kavum nasi dapat dilihat pada Tabel 1. ${ }^{26}$ Cakram antibiotik diletakkan pada permukaan agar dengan sedikit penekanan agar melekat dengan sempurna. Cawan Petri dimasukkan dan diletakkan secara terbalik kedalam inkubator $37^{0} \mathrm{C}$ selama 24 jam. Keesokan harinya dibaca zona hambatan pertumbuhan bakteri berdasarkan kriteria NCCLS untuk ditentukan sensitifitasnya.

Pada penelitian ini, dilaporkan pembacaan cakram antibiotik sebagai sensitif dan resisten. Jenis antibiotik yang digunakan dalam penelitian ini sesuai dengan Standard Operating Procedures SOP in Microbiology, Zone Diameter Interpretive Standard and Equivalent Minimum Inhibitor Concentration pada tabel NCCLS. ${ }^{26}$

\section{HASIL PENELITIAN}

Pada penelitian ini didapatkan 31 petugas yang memenuhi kriteria inklusi. Sebanyak 17 petugas berada di kamar bedah operasi jantung dan 14 petugas di ruang pasca operasi ICCU. 
70 Jurnal e-Biomedik (eBm), Volume 7, Nomor 1, Januari-Juni 2019

Tabel 1. Zone Diameter Interpretive Standard and Equivalent Minimum Inhibitor Concentration ${ }^{26}$

\begin{tabular}{lccc}
\hline \multicolumn{1}{c}{ Jenis Antibiotik } & Disk Content & $\begin{array}{c}\text { Diameter } \\
\text { Resisten }(\mathbf{m m})\end{array}$ & $\begin{array}{c}\text { Diameter } \\
\text { Sensitif (mm) }\end{array}$ \\
\hline Amoksisilin & $10 \mu \mathrm{g}$ & $0-13$ & $\geq 18$ \\
Ampisilin & $10 \mu \mathrm{g}$ & $0-11$ & $\geq 14$ \\
Doksisiklin & $30 \mu \mathrm{g}$ & $0-17$ & $\geq 24$ \\
Penisilin & $10 \mu \mathrm{g}$ & $0-20$ & $\geq 29$ \\
Eritromisin & $15 \mu \mathrm{g}$ & $0-14$ & $\geq 18$ \\
Vankomisin & $30 \mu \mathrm{g}$ & $0-9$ & $\geq 13$ \\
Sefepim & $5 \mu \mathrm{g}$ & $0-22$ & $\geq 30$ \\
Seftriakson & $30 \mu \mathrm{g}$ & $0-21$ & 29 \\
Sefuroksim & $30 \mu \mathrm{g}$ & $0-20$ & $\geq 27$ \\
Siprofloksasin & $5 \mu \mathrm{g}$ & $0-21$ & $\geq 26$ \\
Norfloksasin & $10 \mu \mathrm{g}$ & $0-12$ & $\geq 17$ \\
Amikasin & $30 \mu \mathrm{g}$ & $0-14$ & $\geq 17$ \\
Kotrimoksasol & $1,25 / 23,75 \mu \mathrm{g}$ & $0-10$ & $\geq 16$ \\
Kanamisin & $30 \mu \mathrm{g}$ & $0-13$ & $\geq 18$ \\
Amoksisilin/klavulanat & $20 / 10 \mu \mathrm{g}$ & $0-13$ & $\geq 18$ \\
\hline
\end{tabular}

Petugas pada kamar bedah operasi jantung terdiri dari 5 perawat, 3 perawat tehnisi perfusi yang menguasai alat mesin bypass jantung, 1 dokter jantung, 3 dokter bedah jantung, 2 dokter anastesi, dan 3 cleaning service sedangkan pada pasca operasi ICCU terdiri dari 11 perawat, 1 dokter jantung, dan 2 cleaning service. Tabel 2 memperlihatkan jenis kuman yang tumbuh dari seluruh subyek penelitian.

Tabel 2. Pola kuman pada keseluruhan petugas kamar bedah jantung dan pasca operasi ICCU RSUP H. Adam Malik Medan

\begin{tabular}{lcc}
\hline \multicolumn{1}{c}{ Jenis Kuman } & Frekuensi & \% \\
\hline S. epidermidis & 13 & 40 \\
S. saprophyticus & 7 & 21 \\
S. aureus & 4 & 12 \\
S. xylosus & 2 & 6 \\
S. pyogenes & 1 & 3 \\
P. aeroginosa & 1 & 3 \\
K. pneumonie & 1 & 3 \\
K. ozenae & 1 & 3 \\
Micrococcus spp & 1 & 3 \\
S. viridans & 1 & 3 \\
S. warneri & 1 & 3 \\
Total & 33 & 100 \\
\hline
\end{tabular}

Tabel 3 menampilkan pola kuman pada kamar operasi bedah jantung dan pasca operasi ICCU.

Tabel 4 memperlihatkan distribusi usia dan jenis kelamin petugas yang bekerja di kamar bedah operasi jantung sedangkan Tabel 5 memperlihatkan distribusi usia dan jenis kelamin petugas yang bekerja di pasca operasi ICCU.

Tabel 6 menunjukkan gambaran resistensi berbagai golongan antimikroba di kamar operasi jantung dan pasca operasi ICCU.

\section{BAHASAN}

Infeksi yang didapat dirumah sakit yang ditularkan oleh petugas sangat merugikan baik pasien, maupun pihak rumah sakit. Salah satu penularan kuman dapat terjadi melalui tangan yang umumnya berasal dari kavum nasi; ${ }^{27}$ hal ini selaras dengan tujuan penelitian ini yaitu mendapatkan profil resistensi penularan yang berasal dari kavum nasi.

Pemeriksaan spesimen dari petugas kesehatan yang merawat pasien dapat memberikan data bahwa infeksi nosokomial pada pasien dapat disebabkan oleh para petugas. Pemeriksaan spesimen dapat dilakukan dengan swab di daerah kavum nasi para petugas di Intensive Care Unit, kamar operasi, atau di ruang bangsal. ${ }^{28}$ 
Tabel 3. Pola kuman pada masing masing kamar operasi jantung dan pasca operasi ICU jantung

\begin{tabular}{ccc}
\hline Jenis kuman & Kamar bedah operasi jantung & Pasca operasi ICU jantung \\
\hline S.epidermidis & $8(44 \%)$ & $5(33,30 \%)$ \\
S.saprophyticus & $4(22,2 \%)$ & $3(20 \%)$ \\
S.aureus & $4(22,2 \%)$ & $0 \%$ \\
S. viridans & $1(5,6 \%)$ & $0 \%$ \\
K. ozenae & $1(5,6 \%)$ & $0 \%$ \\
S. xylosus & $0 \%$ & $2(13,3 \%)$ \\
S. warneri & $0 \%$ & $1(6,7 \%)$ \\
P. aeroginosa & $0 \%$ & $1(6,7 \%)$ \\
Micrococcus spp & $0 \%$ & $1(6,7 \%)$ \\
K. pneumonie & $0 \%$ & $1(6,7 \%)$ \\
S. pyogenes & $0 \%$ & $1(6,7 \%)$ \\
Total & $18(100 \%)$ & $15(100 \%)$ \\
\hline
\end{tabular}

Tabel 4. Pengelompokan petugas kamar operasi jantung berdasarkan usia dan jenis kelamin

\begin{tabular}{ccc}
\hline Usia (tahun) & Frekuensi & Persentase \\
\hline$<21$ & 0 & $0 \%$ \\
$21-25$ & 0 & $0 \%$ \\
$26-30$ & 2 & $12 \%$ \\
$31-35$ & 2 & $12 \%$ \\
$>35$ & 13 & $76 \%$ \\
Jenis kelamin & & \\
Laki-laki & 7 & $41 \%$ \\
Perempuan & 10 & $59 \%$ \\
\hline
\end{tabular}

Tabel 5. Pengelompokan petugas pasca operasi ICU jantung berdasarkan usia dan jenis kelamin

\begin{tabular}{ccc}
\hline Usia & Frekuensi & Persentase \\
\hline$<21$ & 1 & $10 \%$ \\
$21-25$ & 0 & $0 \%$ \\
$26-30$ & 3 & $20 \%$ \\
$31-35$ & 8 & $60 \%$ \\
$>35$ & 2 & $10 \%$ \\
Jenis kelamin & & \\
Laki-laki & 3 & $21 \%$ \\
Perempuan & 11 & $79 \%$ \\
\hline
\end{tabular}

Tabel 6. Gambaran resistensi berbagai golongan antimikroba di kamar operasi jantung dan pasca operasi ICU jantung

\begin{tabular}{|c|c|c|c|c|c|c|c|c|c|}
\hline \multirow[t]{3}{*}{ Antibiotik } & \multicolumn{4}{|c|}{ Kamar Operasi Jantung } & \multicolumn{4}{|c|}{ Post-Operasi Jantung } & \multirow[t]{3}{*}{ P value } \\
\hline & \multicolumn{2}{|c|}{$\mathrm{N}$} & \multicolumn{2}{|c|}{$\%$} & \multicolumn{2}{|c|}{$\mathrm{N}$} & \multicolumn{2}{|c|}{$\%$} & \\
\hline & S & $\mathrm{R}$ & S & $\mathrm{R}$ & S & $\mathrm{R}$ & S & $\mathrm{R}$ & \\
\hline Ampisilin & 6 & 12 & 33,3 & 66,7 & 1 & 14 & 6,7 & 93,3 & 0,095 \\
\hline Amoksisilin & 7 & 11 & 38,9 & 66,1 & 2 & 13 & 13,3 & 86,7 & 0,134 \\
\hline Sulfametoksasol & 1 & 17 & 5,6 & 94,4 & 0 & 15 & 0 & 100 & 1,000 \\
\hline Kanamisin & 6 & 12 & 33,3 & 66,7 & 7 & 8 & 46,7 & 53,3 & 0,435 \\
\hline Penisilin & 6 & 12 & 33,3 & 66,7 & 2 & 13 & 13,3 & 86,7 & 0,242 \\
\hline Eritromisin & 10 & 8 & 55,6 & 44,4 & 8 & 7 & 54,5 & 45,5 & 0,898 \\
\hline Amikasin & 6 & 12 & 33,3 & 66,7 & 11 & 4 & 73,3 & 26,7 & $\begin{array}{l}\mathrm{P}=0,022 \\
(\mathrm{P}<0,05)\end{array}$ \\
\hline Doksisiklin & 7 & 11 & 38,9 & 61,1 & 2 & 13 & 13,3 & 86,7 & 0,134 \\
\hline Amoksiklav & 16 & 2 & 88,9 & 11,1 & 10 & 5 & 66,7 & 33,3 & 0,203 \\
\hline Norfloksasin & 13 & 5 & 72,2 & 27,8 & 9 & 6 & 60 & 40 & 0,458 \\
\hline Siproflokasin & 11 & 7 & 61,1 & 38,9 & 7 & 8 & 46,7 & 53,3 & 0,407 \\
\hline Sefuroksim & 11 & 7 & 61,1 & 38,9 & 9 & 6 & 60 & 40 & 0,948 \\
\hline Seftriakson & 12 & 6 & 66,7 & 33,3 & 12 & 3 & 80 & 20 & 0,458 \\
\hline Sefepim & 14 & 4 & 77,8 & 22,2 & 11 & 4 & 73,3 & 26,7 & 1.000 \\
\hline Vankomisin & 1 & 17 & 5,6 & 94,4 & 3 & 12 & 20 & 80 & 0,308 \\
\hline
\end{tabular}


Pada pembedahan toraks jantung, telah banyak tindakan yang dilakukan untuk mencegah transmisi bakteri sewaktu dilakukan operasi. Walaupun demikian pasien tetap mempunyai risiko terhadap infeksi nosokomial pasca operasi. Transmisi dapat terjadi melalui perangkat seperti drain, kateter urin, nasogastric tube, endotracheal tube, yang dapat memberikan jalan masuk untuk bakteri $S$. aureus atau flora normal lainnya dari kavum nasi petugas ke pasien yang dirawat. Semua petugas baik anestesiologis, dokter bedah, perawat, cleaning service dan lainnya dapat masuk dan memanipulasi satu atau lebih perangkat yang memberikan kontribusi terjadinya transmisi bakteri. ${ }^{14}$

Beberapa mikroorganisme telah dilaporkan pada beberapa penelitian sebagai penyebab infeksi nosokomial, terutama yang diambil dan diisolasi dari perlukaan operasi. $^{29}$ Terdapat berbagai mikroorganisme yang ditemukan dalam kavum nasi manusia yang sehat, antara lain $S$. epidermidis, $S$. aureus, $S$. pneumonie, Haemophilus spp, dan S. pyogenes. Mikroorganisme ini dapat mengalami kolonisasi di dalam kavum nasi kemudian mengalami transmisi dari petugas ke pasien-pasien yang sedang dirawat. Staphylococcus dan bakteri lainnya berkolonisasi pada mukosa rongga hidung sebagai flora normal. ${ }^{30,31}$

Pada penelitian ini distribusi usia memperlihatkan bahwa petugas yang bekerja di kamar bedah operasi jantung paling banyak berusia $>35$ tahun, yaitu sebanyak 13 orang (76\%), sedangkan petugas pasca operasi ICCU paling banyak berusia antara 31-35 tahun, yaitu sebanyak 8 orang $(60 \%)$. Penelitian yang dilakukan Hikmawati di Semarang, membandingkan kolonisasi antara anak-anak dan orang tua yang sehat. Dari 150 sampel, didapatkan 79 sampel terkolonisasi bakteri. S. pneumoniae paling banyak ditemukan pada anak-anak $(45,3 \%)$, sedangkan enterobacteriaceae lebih banyak pada orang tua. Selain itu, kolonisasi $S$. aureus lebih banyak ditemukan pada orang tua $(8 \%)$ daripada anak-anak $(6,7 \%){ }^{32}$ Penelitian oleh Ohara-Nemoto et $\mathrm{al}^{33}$ di Jepang mendapatkan 18 dari 60 subjek dengan Staphylococci, yang terbanyak ialah $S$. epidermidis yaitu 13 subyek (72,2\%), diikuti oleh $S$. aureus sebanyak 8 subyek (44\%).

Pada penelitian ini untuk distribusi jenis kelamin petugas didapatkan pada kamar bedah operasi jantung dan pasca operasi ICCU yang terbanyak ialah perempuan yaitu 10 orang (59\%) dan 11 orang (79\%).

Hasil penelitian ini mendapatkan pola kuman dalam kavum nasi pada total 31 orang petugas kamar bedah jantung dan pasca operasi ICCU yang terbanyak ialah $S$. epidermidis sebanyak 13 subyek (40\%). Hasil penelitian oleh Tammelin et $\mathrm{al}^{14}$ di Rumah Sakit Universitas Uppsala, Swedia, mendapatkan $S$. aureus sebanyak 26 dari 133 orang $(19,5 \%)$ petugas kesehatan di Bagian Bedah Kardiovaskular dan Toraks. Pada penelitian tersebut juga diteliti bangsal dari Bagian Bedah Kardiovaskular dan Toraks. Selain pada kavum nasi, juga diteliti sampel swab jari para petugas. Pada penelitian yang dilakukan Farzana et al ${ }^{15}$ terhadap petugas di berbagai bangsal, petugas administrasi, serta pegawai rumah sakit di Children Hospital Complex, Multan dilaporkan bahwa dari 129 sampel didapatkan Staphylococci sebanyak 121 spesimen $(93,8 \%)$, dengan prevalensi $S$. aureus sebesar $48 \%$, methicillin resistant Staphylococcus aureus (MRSA) 13,95\%, dan coagulase negative Staphylococci $45,7 \%$.

Pada penelitian ini, dari kamar bedah operasi jantung didapatkan S. epidermidis sebanyak 8 sampel (44\%), diikuti $S$. saprophyticus dan $S$. aureus masing masing 4 sampel (22,2\%), sedangkan pada pasca operasi ICCU ditemukan $S$. epidermidis sebanyak 5 sampel (33,3\%), diikuti $S$. saprophyticus sebanyak 3 sampel (20\%), dan $S$. xilosus sebanyak 2 sampel $(13,3 \%)$. Tammelin et $\mathrm{al}^{14}$ melaporkan terdapatnya S. aureus pada kamar bedah jantung sebanyak 7 dari 37 orang $(15,6 \%)$, sedangkan pada pasca operasi ICCU sebanyak 11 dari 50 orang $(19,3 \%)$, dan dari bangsal 5 dari 28 orang $(25,8 \%)$.

Pada penelitian ini didapatkan profil resistensi terhadap antimikroba amoksisilin 
dan sulfametoksasol pada mikroba kavum nasi petugas kamar bedah operasi jantung dan petugas pasca operasi ICCU cukup tinggi; hal ini dapat disebabkan seringnya pemberian resep antimikroba tersebut oleh para klinisi, demikian pula dengan ampisilin, amikasin, doksisiklin, eritromisin dan penisiin. Penyalahgunaan antibiotik dapat membuat munculnya resistensi bakteri.

Data AMRIN (Antimicrobial Resistance in Indonesia: prevalency and prevention) yang dilakukan di Semarang dan Surabaya, memperlihatkan pemakaian obat antibiotik yang tertinggi ialah ampisilin dan amoksisilin (71\%); pada urutan kedua ialah tetracycline $(9 \%)$ dan selanjutnya kotrimoksasol (8\%). Sebagian besar antibiotik diresepkan oleh dokter, yaitu praktek pribadi $37 \%$, puskesmas $29 \%$, dan rumah sakit $13 \%$. Sebesar $6 \%$ antibiotik diberikan oleh perawat dan bidan tanpa menggunakan resep. Juga ditemukan sekitar 20\% antibiotik digunakan sebagai pengobatan diri sendiri. Antibiotika yang paling resisten ialah ampisilin dan kotrimoksasol. ${ }^{34}$

Masih menjadi perdebatan bila terdapat penurunan penggunaan antimikroba, apakah nantinya juga dapat terjadi penurunan resistensi terhadap antimikroba tersebut. Meskipun terjadi penurunan penggunaan ampisilin dan penisilin, ternyata masih terjadi resistensi terhadap antibiotika ini. Diduga hal ini terjadi oleh karena adanya residu dari penggunaan antibiotika yang digunakan pada pertanian dan peternakan. ${ }^{35}$

Pada penelitian ini (Tabel 6), didapatkan resistensi terhadap amikasin pada kamar operasi bedah jantung. Resistensi tersebut terjadi oleh karena terjadinya penurunan dalam pengambilan serta akumulasi obat akibat adanya membran yang impermeabel, tetapi mekanismenya belum diketahui pasti. Terdapatnya enzim aminoglikosidase yang dimodifikasi yang mengatalisis fungsi amino yang spesifik, dapat memodifikasi obat sehingga terbentu ikatan yang lemah antara obat dan ribosom, yang menghambat penyerapan obat. ${ }^{36}$

Adanya peningkatan konsumsi terhadap siprofloksasin juga menyebabkan terjadinya peningkatan resistensi terhadap antimikroba ini. Resistensi siprofloksasin terjadi oleh karena adanya mutasi pada gen yang mengode enzim target, yaitu gyr A dan gyr B, dan juga oleh karena adanya penurunan akumulasi intrasel. ${ }^{37}$

Pada penelitian ini didapatkan resistensi bakteri Gram positif terhadap vankomisin. Pada berbagai literatur dinyatakan bahwa terdapat 6 tipe resistensi terhadap vankomisin yaitu VanA, VanB, VanD, VanE, VanG, dan VanC. VanA merupakan tipe resistensi yang tersering dari resistensi terhadap glikopeptida pada enterococci, dan sekarang ini merupakan satu-satunya yang terdeteksi pada Staphylococcus aureus. ${ }^{38,39}$

\section{SIMPULAN}

Berdasarkan hasil penelitian ini dapat disimpulkan bahwa bakteri terbanyak ditemukan ialah golongan Gram positif Staphylococcus dan S. epidermidis. Vankomisin merupakan antimikroba paling resisten. Juga didapatkan resistensi terhadap antimikroba lainnya yaitu ampisilin, amoksisilin, sulfametoksasol, kanamisin, penisilin, eritromisin, amikasin, dan doksisiklin sedangkan antimikroba yang masih sensitif ialah amoksiklav, golongan sefalosporin, dan norfloksasin.

\section{DAFTAR PUSTAKA}

1. Ducel G, Fabry J. Prevention of hospital aquired infections a practical guide. Geneva: World Health Organisation, 2002; p. 1-8.

2. Parker MT. Hospital-acquired; guideline to laboratory methods. Geneva: World Health Organization, 1978; p. 5-40.

3. Ginting Y, Bachtiar P. Pencegahan infeksi nosocomial. In: Makalah Seminar Ilmiah Tahunan II Bagian Ilmu Penyakit Dalam. Medan, FK USU, 2001.

4. Eggimann P, Pittet D. Infection control in the ICU. Chest. 2001;120(6): 2059-93.

5. Terrie YC. Nosocomial infections: impact on patient care. Pharmacy Times, March 01, 2006.

6. Albrich WC, Harbarth S. Health care workers: source, vector, or victim of 
MRSA, Lancet Infect Dis. 2008; 8(5):289-301.

7. Bolyard EA, Tablan OC, Williams WW, Pearson ML, Shapiro CN, Deitchmann SD. Guideline for infection control in healthcare personnel 1998. Infect Control Hosp Epidemiol. 1998;19(6):407-63.

8. Brooks GF, Carroll KC, Butel JS, Morse SA. Jawetz, Melnick \& Adelberg Mikrobiologi Kedokteran. Jakarta: EGC, 2007; p. 198-2003.

9. Koneman EW, Allen SD, Janda WM, Schreckenberger PC. Koneman's Color Atlas and Textbook of Diagnostic Microbiology (6th ed). Washington: Lippincott Wiliams and Wilkins, 2006; p. 431-1014.

10. Strohl WA, Rouse H, Rouse W, Fisher BD, Champe PC, Harvey RA. Microbiology. Philadelphia: Lippincott Williams and Wilkins, 2001; p. 7-10.

11. Saene HKFV, Silvestri MADLC. Infection Control in Intensive Care Unit (2nd ed). Springer, 2005; p. 49-58.

12. Minasari N. Pengantar Mikrobiologi. Medan: USU press, 2010; p. 58-71.

13. Goldman E, Green LH. Practical Handbook of Microbiology (2nd ed). Boca Raton: CRC Press, 2009; p. 275-519.

14. Tammelin A, Klotz F, Hambraeus A, Stahle E, Ransjo U. Nasal and hand carriage of Staphylococcus aureus in staff at Departement for Thoracic and Cardiovascular Surgery: endogenous or exogenous source? Infect Control Hosp Epidemiol. 2003; 24(9):686-9.

15. Farzana K, Rashid Z, Akhtar N, Sattar A, Khan JA, Nasir B. Nasal carriage of staphylococci in health care workers: antimicrobial susceptibility profil. Pak J Pharm Sci. 2008;21(3):290-4.

16. Levinson W. Review of Medical Microbiology and Immunology (10th ed). New York: Mc Graw Hill, 2006; p. 106-18.

17. Shetty N, Tang JW, Andrews J. Infectious Disease: Pathogenesis, Prevention, and Case Studies (1st ed). Chichester: Wiley-Blackwell, 2009; p.193-4.

18. Busato RC, Gabardo J, Leao MT. Evolution of the resistance of Staphylococcus aureus found on healthcare worker correlated with local consumption of antibiotics. Braz J
Infect Dis. 2006;10(3):185-90.

19. Jakob HG, Borneff-Lipp M, Bach A, von Puckler S, Windeler J, Sonntag H, et al. The endogenous pathway is a major route for deep sternal wound infection. Eur J Cardiothorac Surg. 2000;17(2): 154-60.

20. Khalili MB, Sharifi-Yazdi MK, Dargahi H, Sadeghian HA. Nasal colonisation rate of Staphylococcus aureus strains among health care service employee's of Teaching University Hospitals in Yazd. Acta Medica Iranica. 2009; 47(4):315-7.

21. Prosedur Tetap Mikrobiologi Instalasi Patologi Klinik, RSUP H. Adam Malik Medan.

22. Hardjeno H, Essa T, Nurhayana. Kumpulan Penyakit Infeksi dan Tes Kultur Sensitivitas Kuman serta Upaya Pengendaliannya. Makassar: Cahya Dinar Rucitra, 2007; p. 5-13.

23. Malik CP, Mustafa MI. Identifikasi mikroba metode pewarnaan Gram. J Prakt Mikrobiol Umum. 2017; 1(1):1-6.

24. BioMerieux . Methodologies Procedure of API, 2009.

25. Atlas RM, Synder JW. Handbook of Media for Clinical Microbiology. Boca Raton, Taylor \& Francis, 2002; p. 130-2.

26. NCCLS. Standard operating procedure (SOP) in microbiology zone diameter interpretive standard and equivalent minimum inhibitor concentration.

27. Baharutan A, Rares FE, Soeliongan S. Pola bakteri penyebab infeksi nosokomial pada Ruang Perawatan Intensif Anak di BLU RSUP Prof. Dr. R. D. Kandou Manado. eBm. 2015;3(1):4129.

28. Warganegara E, Apriliana E, Ardiansyah R. Identifikasi bakteri penyebab infeksi luka operasi ( ILO) nosokomial pada Ruang Rawat Inap Bedah dan Kebidanan RSAM di Bandar Lampung. Prosiding SNSMAIP III-2012. ISBN No. 978-602-98559-1-3.

29. Malik RHA, Puspitasari N, Tarigan M. Gambaran cuci tangan perawat di ruang RA, RB, ICU, CVCU, RSUP H. Adam Malik Medan. 2012. Available from: jurnal.usu. ac.id/index.php/jkk/article/ download/1259/646 p. 4-6.

30. Arghyros M. Guidelines for assuring quality of medical microbiological culture 
media; 1996.

31. Pedoman Praktek Laboratorium yang Benar. Jakarta: Departemen Kesehatan Republik Indonesia, 2003; p. 90-3.

32. Hikmawati. Perbedaan pola kolonisasi bakteri potensial patogen respiratori pada nasofaring anak anak dan orangtua sehat [Artikel Ilmiah]. Semarang: Universitas Diponegoro; 2010.

33. Ohara-Nemoto Y, Haraga H, Kimura S, Nemoto TK. Occurrence of staphylococci in the oral cavities of healthy adults and nasal-oral tarfficking of the bacteria. J Med Microbiol. 2008;57:959.

34. Directorate General of Medical Care Ministry of Health, Republic Indonesia. Antimicrobial resistance. Antibiotic usage and infection control, 2005.

35. Busato CR, Gabardo J, Leao MTC. The evolution of resistance of Staphylococcus aureus found on healthcare workers correlated with local consumption of antibiotics, Braz J Infect Dis. 2006;10(3):185-90.

36. Leclercq M, Paule M, Glupczynski Y, Tulkens PM. Aminoglycosides: activity and resistance. Antimicrob Agents Chemother. 1999;43(4):727-37.

37. Tanaka M, Wang T, Onodera Y, Uchida Y, Sato K. Mechanisme of quinolon resistance in Staphylococcus aureus. J Infect Chemother. 2000;6(3):131-9.

38. Courvalin P. Vancomycin resistance in Gram-positive cocci. Clin Infect Dis. 2006;42(S1):S25-34.

39. Tenover FC. Mechanisms of anti-microbial resistance in bacteria. Am $\mathrm{J}$ Med. 2006;119(6 Supl 1):S3-10. 